\title{
A daily soil temperature model based on air temperature and precipitation for continental applications
}

\author{
Daolan Zheng, E. Raymond Hunt Jr, Steven W. Running \\ School of Forestry, University of Montana, Missoula, Montana 59812, USA
}

\begin{abstract}
Soil temperature is a necessary component for estimating below-ground processes for continental and global carbon budgets; however, there are an insufficient number of climatic stations monitoring soil temperature. We used an 11-day running average of daily mean air temperature to estimate daily mean soil temperature at a depth of $10 \mathrm{~cm}$ using linear regression. This model was tested using data from 6 climate regions across the United States. Frequency analyses for 17 of 19 data sets showed that the number of days which were within a $\pm 3.5^{\circ} \mathrm{C}$ range centered on the measured soil temperature varied from 77 to $96 \%$. The values of $\mathrm{R}^{2}$ between observed and final predicted soil temperatures ranged from 0.85 to 0.96 with standard errors from 1.5 to $2.9^{\circ} \mathrm{C}$ for all 19 simulations. Changes of soil temperature under snow cover were smaller than those without snow cover. Soil temperature under vegetation cover was also simulated assuming the rate of soil warming under vegetation cover would be reduced with increasing leaf area index according to the Beer-Lambert Law. Annual soil respiration can be estimated from the predicted soil temperature with reasonable accuracy. Daily soil temperature may be predicted from daily air temperature once regional equations have been established, because weather stations in the United States can be generalized into a few regions and sites within each region may use the same equation.
\end{abstract}

\section{INTRODUCTION}

Soil temperature is a critical variable controlling below-ground processes for global and continental carbon budgets. Whereas many stations across the United States have long-term records of daily air temperature and precipitation, few climate stations monitor soil temperature. Toy et al. (1978) used monthly mean air temperature to predict monthly soil temperature at continental scales. However, the influence of soil temperature on soil decomposition and respiration is exponential rather than linear (Edwards 1975, Raich \& Schlesinger 1992), so simulations of belowground ecosystem processes for continental scales based on monthly time steps may be biased. Thus, a daily model of soil temperature is necessary.

Many analyses of soil temperature are based on the theories of heat flow and energy balance (Campbell
1977, Parton 1984, Stathers et al. 1985, Nobel \& Geller 1987, Thunholm 1990). Theory-based models may provide accurate estimates of soil temperature at small scales, but may not be practical for estimation of soil temperature at continental and global scales. The many parameters required may depend on topography, soil texture, and soil water content - all of which may vary over short distances. Hasfurther \& Burman (1974) used daily air temperature as a driving variable to predict daily soil temperature through a Fourier series analysis; but the model could be run only after convolution coefficients and correction factors were defined for a particular site. Models requiring coefficients that are defined for each particular site are also not practical for simulations over many different sites.

The objectives of this study are: (1) to develop a general methodology for estimation of daily soil temperature at continental scales using daily air tempera- 
ture and precipitation data for bare ground; (2) to demonstrate how the predictions of soil temperature would effect annual soil respiration assuming different $Q_{10}$ values; and (3) to simulate soil temperature under vegetation based on leaf area index (LAI). LAI can be remotely sensed from satellites (Tucker 1979, Asrar et al. 1984, Running et al. 1986, Peterson et al. 1987, Nemani \& Running 1989). Thus, one may use remote sensing data with climate data to predict soil temperatures at continental scales.

\section{BACKGROUND}

Air temperature correlates well with soil temperature because both are determined by the energy balance at the ground surface. The daily amplitude of soil tempcrature at the surface is greater than the daily amplitude of air temperature for clear days and is less for cloudy days. A depth of $10 \mathrm{~cm}$ was selected for soil temperatures because most soil ecosystem processes occur within the top layers of soil (Buringh 1984, Pritchett \& Fisher 1987). This model was developed first to estimate soil temperatures for bare ground because the soil temperature data obtained from weather stations are usually measured in places with little or no vegetation. Furthermore, vegetation can influence greatly the surface energy balance (Čermák et al. 1992), so it is necessary to adjust predicted bare-soil temperatures for different LAIs.

A time lag exists between air and soil temperatures due to the relatively large heat capacity of the ground. Nevertheless, typical lags between air temperature and soil temperature at a depth of $10 \mathrm{~cm}$ are approximately $4 \mathrm{~h}$ for minimum temperatures and $6 \mathrm{~h}$ for maximum temperatures (Lee 1978). As these time lags are less than $24 \mathrm{~h}$, the same day's data may be used for model predictions of mean soil temperature. Soil temperature for a given day is usually considered to be the result of air temperatures in the past several days.

If snow is present, the relationship between air and soil temperatures will be different from that without snow due to insulation of the snow. Although the depth of snow cover on the ground may influence the rate of change in soil temperature, this influence is not considered in the model.

Between temperatures of 0 and $5^{\circ} \mathrm{C}$, root growth of most plants and germination of most seeds are inhibited (Soil Conservation Service 1975). Below-ground biochemical processes usually become inactive when soil temperature is below freezing. Therefore, whenever the predicted daily soil temperature is below $0^{\circ} \mathrm{C}$, it is assigned as $0^{\circ} \mathrm{C}$.

\section{MODEL DESCRIPTION}

\section{Prediction of soil temperature under bare ground}

The input data required are: (1) daily maximum air temperature $\left({ }^{\circ} \mathrm{C}\right) ;(2)$ daily minimum air temperature $\left({ }^{\circ} \mathrm{C}\right)$; and (3) daily precipitation ( $\left.\mathrm{mm}\right)$. Daily mean soil and air temperatures were calculated as the simple average of the daily maximum and minimum values Daily maximum and minimum soil temperature data are available from the National Oceanic and Atmospheric Administration, Asheville, NC, USA. Daily maximum and minimum air temperature and precipitation data were obtained from EarthInfo, Inc. (Boulder, CO, USA; original source was the National Climatic Data Center). Selection of air temperature and precipitation data as driving variables is based on: (1) daily data are readily available; and (2) soil temperature may be more controlled by climate at large scales.

Eleven-day running averages of daily air temperature were processed on a yearly basis. An 11-day running average was selected after comparing preliminary results using 5-day to 31-day running averages. Running averages were determined in order to reduce the effects of extremes in air temperature. For the 11 -day running averages, averaged air temperature on Julian Day 11 was the mean value of air temperatures from Julian Day 1 to Julian Day 11. Values of air temperature on the first $10 \mathrm{~d}$ were calculated using 1 -day to 10 -day running averages respectively. The 11-day running averages of dir temperature were used as the independent variable and observed daily soil temperatures at $10 \mathrm{~cm}$ depth (without smoothing) as the dependent variable to establish linear regression equations for the 7 model development sites (Fig. 1).

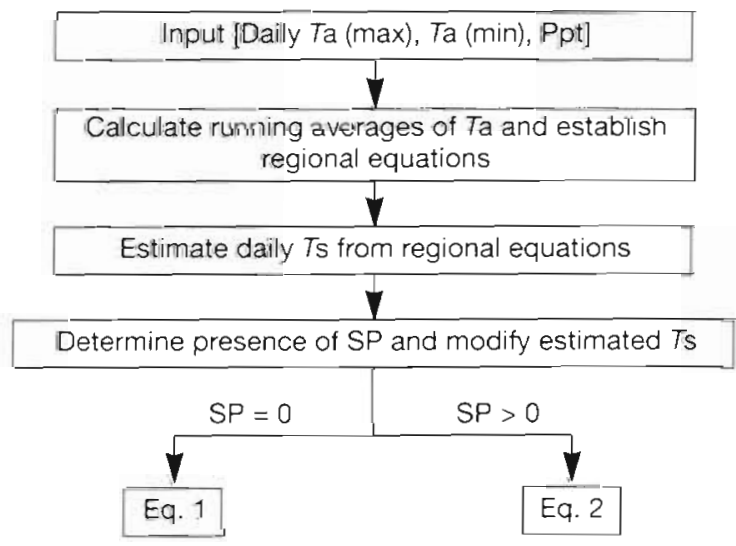

Fig. 1 Flow chart for predicting daily soil temperature from daily aur temperature and precipitation data. Ta: daily mean air temperature in ${ }^{\circ} \mathrm{C}$; $T$ s: daily mean soll temperature in ${ }^{\circ} \mathrm{C}$; SP: amount of snowpack on the ground (water equivalent in $\mathrm{mm})_{i}$ Ppt: precipitation in $\mathrm{mm}$ 
The model calculates 1 -dimensional snowpack (water equivalent in $\mathrm{mm}$ ) on the ground according to the air temperature and precipitation data. The snowpack increases whenever the daily mean air temperature is below or equal to $0^{\circ} \mathrm{C}$ and precipitation occurs on the same day; otherwise, there is no change in snowpack The snowpack decreases or disappears whenever the mean air temperature is above $0^{\circ} \mathrm{C}$

An initial value of snowpack (1-dimensional water equivalent in $\mathrm{mm}$ ) and a snow-melt coefficient $(\mathrm{mm}$ $\mathrm{d}^{-1}{ }^{\circ} \mathrm{C}^{-1}$ ) are required as inputs. The depth of snowpack determines the day of the year when snow disappears. As the simulations begin on the first day of the year, the initial value for the depth of snowpack is based on data for the previous year, if available; otherwise, an estimated value is selected based on site information. The initial values for depth of snowpack in the model simulations varies from 0 to $30 \mathrm{~mm}$. Snowmelt coefficients also vary from site to site and year to year because the 'quality' of snow can influence the melting rate. Therefore, estimated values for the snow melt coefficient are based on general site information, and varies from 0.3 to $1.2 \mathrm{~mm} \mathrm{~d}^{-1}{ }^{\circ} \mathrm{C}^{-1}$.

Estimated daily soil temperatures from the regional equations were modified according to determination of snowpack on the ground, because the rate of change in soil temperature under snow cover will be less due to snow's low thermal diffusivity and high albedo. When air temperature is above freezing, the snowpack will melt and the melt water will increase the heat capacity of the soil. Therefore, whenever a snowpack is present, soil temperature on the current day will not change much compared with the soil temperature on the previous day and Eq. (1) is used:

$$
F(\mathrm{~J})=[A(\mathrm{~J})-A(\mathrm{~J}-1)] \cdot M_{1}+E(\mathrm{~J}-1)
$$

where $F(J)$ is the modified soil temperature on Day $\mathrm{J}$ starting on Julian Day 2, and the value of $F(1)$ is assumed to be $E(1) ; A(J)$ and $A(J-1)$ are the observed daily air temperature on the current day and previous day respectively; $E(\mathrm{~J}-1)$ is the soil temperature on the previous day solely estimated from the regional regression equation; and $M_{1}$ is a rate scaler of 0.1 . When snowpack is not present, Eq. (2) is used:

$$
F(\mathrm{~J})=[A(\mathrm{~J})-A(\mathrm{~J}-1)] \cdot M_{2}+E(\mathrm{~J})
$$

where $E(J)$ is the soil temperature estimated from the regression equation on the current day; and $M_{2}$ is a rate scaler of 0.25 . $E(\mathrm{~J})$ was used for $\mathrm{Eq}$. (2) because the predicted temperatures have smaller errors than those using $E(\mathrm{~J}-1)$.

The rate scalers $M_{1}$ and $M_{2}$, were selected initially from regressions of the running average of air temperature and the observed soil temperature for each site. Except for Alaska, the scalers were similar in magnitude, so in order to make the model simpler and more useful at large scales, constant values for $M_{1}$ and $M_{2}$ were used for all 7 model development sites. The annual means of the predicted soil temperatures using constant scalers were less than $0.6^{\circ} \mathrm{C}$ different from those predicted from the regressions (except Alaska)

\section{Prediction of soil temperature under vegetation}

Experimental studies have shown that vegetation canopies can lower soil temperature during growing season significantly and reduce mean annual soil temperature (Li 1926, Jemison 1934, Qashu \& Zinke 1964, Armson 1977, Munn et al. 1978, Cermák et al. 1992). Qashu \& Zinke (1964) concluded that lower soil temperatures under aak or pine canopies may result from a lower rate of soil warming during spring time, whereas the rate of soil cooling is the same with or without canopy cover.

We hypothesize that a lower rate of soil warming under vegetation canopies results when less radiation is absorbed by the soil. According to the Beer-Lambert law, the fraction of radiation transmitted through a canopy is equal to $e^{(-K \cdot L A l)}$, where $K$ is the extinction coefficient and LAI is the 1 -sided leaf area index. Typical values of $K$ are about 0.5 for different forest species (Jarvis \& Leverenz 1984).

After estimation of daily soil temperature for bare ground, Eq. (3) is used for simulating soil temperatures under vegetation cover when $A(J)>T(J-1)$ :

$\left.T(\mathrm{~J})=T(\mathrm{~J}-1)+[A(\mathrm{~J})-T(\mathrm{~J}-1)] \cdot M_{2} \cdot \exp ^{1-K \cdot L A]}\right)$

where $T(\mathrm{~J})$ and $T(\mathrm{~J}-1)$ are the mean soil temperatures under vegetation on the current day and previous day respectively; and $A(\mathrm{~J})$ is the mean air temperature on the current day. When $A(J) \leq T(J-1)$, Eq. (4) is used:

$$
T(\mathrm{~J})=T(\mathrm{~J}-1)+[\mathrm{A}(\mathrm{J})-T(\mathrm{~J}-1)] \cdot M_{2} .
$$

For evergreen conifers, the correction for LAI begins on Julian Day 2, and the soil temperature for the first day is determined as above.

\section{METHODS}

\section{Selection of sites}

Climatic regions can be defined using different principles for different scales from a single country to the whole globe. We used the Köppen climate classification (Strahler \& Strahler 1989) modified with information from the National Climatic Data Center (NCDC) for the conterminous U.S. (Karl et al. 1988). 
A total of 19 data sets of daily soil temperature at a $10 \mathrm{~cm}$ depth were selected for this study. Seven sites representing 6 different Köppen climatic regions in the USA were used to develop the model and establish the regional equations. The model was then tested both temporally using 7 data sets and spatially using 5 data sets. The years chosen for each site were selected on the basis of having the fewest number of days with missing data. Daily soil temperature for forested sites with known LAI could not be obtained.

\section{Sites used for model development}

The 7 selected sites are described in Table 1 . They are: (1) Milton, Florida (FL84), representing a humid, warm-summer climate (Cfa); (2) Corvallis (Oregon State University), Oregon (OR84), a maritime, coolsummer site with little or no snow cover during the year (Cb); (3) Chatham Experimental Farm, Michigan (MI87), a humid-continental, cool-summer site with a long period of snow cover during the year (Dfb); (4) Jackson Experimental Station, Tennessee (TN84), a humid, warm-summer-site (Cfa); (5) Western Montana Branch Station, Montana (MT80), a cold and dry site $(\mathrm{H}) ;(6)$ Old Edgerton, Alaska (AK84), a subarctic site (DfC); and (7) Safford, Arizona (AZ85), a subtropical desert site (BWh). Latitude ranges from 30.8 to $61.8^{\circ} \mathrm{N}$ among the 7 sites. Elevation ranges from 66 to $1096 \mathrm{~m}$ above sea level. Soils vary in texture from cobbly loam to clay loam; soil cover is either grass, sod or none. There is little variation in slope. Six of the 7 regional equations were generated using all $365 \mathrm{~d}$ of data for the given year; the regional equation for the site in Alaska, 1984, was generated using only the days when observed mean soil temperatures were $\geq 0^{\circ} \mathrm{C}$.

\section{Data sets used for model testing}

Twelve more data sets were used to test the model. Seven were from the same development sites but collected during different years to test the stability of the model over time (Table 2). Five different sites whose climatic types are similar to 5 of the 7 model development sites were used to test whether the model can be extended to large spatial scales (Table 3). The 5 sites are: (1) Gainesville, Florida (FL84p, paired with FL84); (2) New Mexico State University at Las Cruces, New Mexico (NM85p, paired with AZ85); (3) Geneva, New York (NY87p, paired with MI87); (4) Creston, Montana (MT80p, paired with MT80); (5) Raleigh-Durham, North Carolina (NC83p, paired with TN84). Data sets to pair with the model development sites in Oregon and Alaska were unavailable.

Table 1 Information for the 7 sites in different climatic regions across the United States. The data sets from these 7 sites were used for model development and establishing regional equations

\begin{tabular}{|c|c|c|c|c|c|c|c|}
\hline $\begin{array}{r}\text { Site: } \\
\text { Location (U.S. state) }\end{array}$ & $\begin{array}{l}\text { Cfa } \\
\text { FL }\end{array}$ & $\begin{array}{l}\mathrm{H} \\
\mathrm{MT}\end{array}$ & $\begin{array}{l}\mathrm{Cb} \\
\mathrm{OR}\end{array}$ & $\begin{array}{l}\mathrm{Dfb} \\
\mathrm{MI}\end{array}$ & $\begin{array}{l}\mathrm{Cfa} \\
\mathrm{TN}\end{array}$ & $\begin{array}{l}\text { BWh } \\
\text { AZ }\end{array}$ & $\begin{array}{l}\mathrm{DfC} \\
\mathrm{AK}\end{array}$ \\
\hline Year & 1984 & 1980 & 1984 & 1987 & 1984 & 1985 & 1984 \\
\hline Abbreviation & FL.84 & MT80 & OR84 & MI87 & TN84 & AZ85 & AK84 \\
\hline Latitude $\left({ }^{\circ}\right)$ & 30.8 & 46.3 & 44.6 & 46.4 & 35.6 & 32.8 & 61.8 \\
\hline Longitude ( W) & 87 & 114 & 123 & 87 & 89 & 110 & 145 \\
\hline Elevation (m) & 66 & 1096 & 69 & 267 & 122 & 900 & 402 \\
\hline Soil type & $\begin{array}{l}\text { Sandy } \\
\text { loam }\end{array}$ & $\begin{array}{l}\text { Cobbly } \\
\text { Ioam }\end{array}$ & $\begin{array}{l}\text { Clay } \\
\text { loam }\end{array}$ & $\begin{array}{l}\text { Sandy } \\
\text { loam }\end{array}$ & Lintonia & $\begin{array}{l}\text { Clay } \\
\text { loam }\end{array}$ & $\begin{array}{c}\text { Clay \& sandy } \\
\text { loam }\end{array}$ \\
\hline Cover & Bare & Grass & Unknown & Sod & Grass & Bare & Sod \\
\hline Slope $(\%)$ & 2 & 2 & 2 & 3 & 0 & 0 & 0 \\
\hline Aspect $\left.1^{\circ}\right)$ & 90 & 180 & 250 & 180 & - & - & - \\
\hline $\operatorname{Jan} \mathrm{Ta}^{\mathrm{dt}}$ & 8.0 & -6.5 & 5.5 & -6.6 & -0.3 & 5.9 & -15.7 \\
\hline Jul Ta & 26.3 & 18.5 & 18.9 & 20.2 & 25.3 & 28.7 & 12.8 \\
\hline Ann. Ta & 19.2 & 7.5 & 10.9 & 6.8 & 15.1 & 17.3 & -1.5 \\
\hline Ann. $T \mathrm{~s}^{b}$ & 22.5 & 12.1 & 12.8 & 8.2 & 15.7 & 19.5 & 0.8 \\
\hline Ann. $\Delta T^{c}$ & 3.3 & 4.6 & 1.9 & 1.4 & 0.6 & 2.2 & 2.1 \\
\hline Ann $p p^{\mathrm{d}}$ & 1539 & 448 & 1234 & 828 & 1372 & 300 & 278 \\
\hline \multicolumn{8}{|l|}{ Missing data ${ }^{e}$} \\
\hline Air & 0 & 13 & 0 & 0 & 0 & 2 & 0 \\
\hline Soil & 0 & 3 & 0 & 0 & 0 & 4 & 0 \\
\hline \multicolumn{5}{|c|}{$\begin{array}{l}{ }^{\mathrm{D}} \mathrm{Ta}=\text { mean air temperature }\left({ }^{\circ} \mathrm{C}\right) \text { for January, July, and for year } \\
{ }^{\mathrm{T}} \mathrm{Ts}=\text { mean soil temperature }\left({ }^{\circ} \mathrm{C}\right) \text { for January, July, and for year } \\
\text { Difference of annual mean soil temperature and mean air temperature }\end{array}$} & \multicolumn{3}{|c|}{$\begin{array}{l}\text { ¿Annual precipitation }(\mathrm{mm}) \\
\text { eNo. of days during the yedr when data } \\
\text { are missing }\end{array}$} \\
\hline
\end{tabular}


Table 2. Information for a second year of data for the 7 model development sites. These 7 data sets collected during different years were used for a temporal test of the model See Table 1 for explanation of symbols

\begin{tabular}{|lccccccc|}
\hline & FL & MT & OR & MI & TN & AZ & AK \\
\hline Year & 1987 & 1983 & 1988 & 1989 & 1987 & 1989 & 1989 \\
Abbrev. & FL87 & MT83 & OR84 & MI89 & TN87 & AZ89 & AK89 \\
Jan Ta & 8.5 & 1.0 & 4.0 & -4.5 & 3.0 & 6.5 & -23.0 \\
Jul Ta & 27.0 & 17.0 & 19.5 & 20.5 & 26.5 & 28.5 & 16.0 \\
Ann. Ta & 18.5 & 7.5 & 11.5 & 5.5 & 16.0 & 18.0 & -1.5 \\
Ann. ppt & 1844 & 311 & 953 & 620 & 1295 & 123 & 313 \\
Missing data & & & & & & & \\
Air & 0 & 0 & 0 & 0 & 0 & 0 & 2 \\
Soil & 0 & 0 & 0 & 0 & 0 & 0 & 0 \\
\hline
\end{tabular}

\section{Estimations of annual soil respiration}

It has long been recognized that soil respiration rate increases exponentially with temperature; respiration increases about 2.4 times for a $10^{\circ} \mathrm{C}$ increase in temperature $\left(Q_{10}=2.4\right)$ (Raich \& Schlesinger 1992). We chose $Q_{10}$ values of $2.0,2.4$, and 3.0 to examine how the range in measured $Q_{10}$ 's affected the relative errors of annual soil respiration calculated from the predicted and measured soil temperatures.

Daily soil respiration is calculated as a specific rate times a function of daily soil temperature; daily soil respiration is then summed over a year to obtain the annual value. If the specific rate does not change over

Table 3. Information for different sites which were paired with 5 of 7 model-development sites. The data sets from these 5 different sites were used for a spatial test of the model. See Table 1 for explanation of symbols

\begin{tabular}{|lccccc|}
\hline & FL & NM & NC & NY & MT \\
\hline Year & 1984 & 1985 & 1983 & 1987 & 1980 \\
Abbrev. & FL84p & NM85p & NC83p & NY87p & MT80p \\
Paired site & FL. & AZ & TN & MI & MT \\
Lat. $\left({ }^{\circ} \mathrm{N}\right)$ & 29.6 & 32.3 & 35.9 & 42.9 & 48.2 \\
Long. $\left({ }^{\circ} \mathrm{W}\right)$ & 82 & 107 & 79 & 77 & 114 \\
Elev. $(\mathrm{m})$ & 29 & 1183 & 115 & 219 & 896 \\
Soil type & Sandy & Belen & Silty & Silt & Silt \\
& loam & clay & loam & loam & loam \\
Cover & Bare & Bare & Sod & Sod & Bare \\
Slope $(\%)$ & 6 & 0 & 5 & $0-3$ & 2 \\
Aspect $\left({ }^{\circ}\right)$ & 315 & - & 225 & 90 & 180 \\
Jan Ta & 12.0 & 4.0 & 3.5 & -3.5 & -8.5 \\
Jul Ta & 26.5 & 26.5 & 26.5 & 22.0 & 17.5 \\
Ann. Ta & 21.5 & 16.5 & 15.0 & 9.0 & 6.5 \\
Ann. ppt & 997 & 319 & 1200 & 862 & 627 \\
Missing data & & & & & \\
Air & 0 & 0 & 0 & 0 & 0 \\
Soil & 0 & 0 & 0 & 0 & 0 \\
& & & & & \\
\hline
\end{tabular}

the year, then predicted relative annual soil respiration ( $Y_{p}$, unitless) is calculated from the temperature function alone:

$$
Y_{\mathrm{p}}=\sum \exp [X \cdot F(\mathrm{~J})]
$$

where $F(J)$ is the predicted soil temperature on Julian Day $\mathrm{J}$ (starting from Julian Day 1 to 365 ) and $X$ is 0.07 , $0.09,0.11$ for $Q_{10}$ 's of $2.0,2.4$, or 3.0 , respectively. Measured relative annual soil respiration ( $Y_{m}$, unitless) is calculated by:

$$
Y_{\mathrm{m}}=\sum \exp [X \cdot G(\mathrm{~J})]
$$

where $G(J)$ is daily measured soil temperature for each of the 7 model development sites. Errors in annual soil respiration were then determined by:

$$
\%_{\text {error }}=\left(Y_{\mathrm{p}}-Y_{\mathrm{m}}\right) / Y_{\mathrm{m}} \cdot 100 \%
$$

\section{Statistical analyses}

An aggregated equation including all 7 modeldevelopment sites was also produced and $F$ tests [defined as MSE1/MSE2 where MSE is the mean square error or residual mean square, and the larger MSE is taken as numerator (Neter et al. 1990)] were used to determine whether there were significant differences between each of the 7 regional equations and the aggregated equation. A dummy variable was created for the aggregated equation and a $t$-test was used to determine whether there were significant differences among the 7 model-development sites. Frequency analysis was used to determine the accuracy of model prediction.

\section{RESULTS AND DISCUSSION}

There were strong relationships between the averaged daily air temperatures and observed daily soil temperatures at the $10 \mathrm{~cm}$ depth for all 7 model development sites; $R^{2}$ values ranged from 0.86 to 0.97 (Fig. 2). With the exception of Oregon (due to its maritime climate), the absolute value of the regression intercepts increased with the increase in latitude, perhaps because the sites located in higher latitude usually have greater variability of air and soil temperatures. At a similar latitude, a moist site (MI) has a smaller variation than that of a dry site (MT).

These 7 linear regressions were considered as regional equations. The relationship between observed and estimated soil temperatures will be exact if the intercept $\left(b_{0}\right)=0$ and the slope $\left(b_{1}\right)=1 ; b_{0}$ and $b_{1}$ for 6 of the 7 development sites were not significantly different from 0 and 1, respectively (data not shown). The poor correlation for the Alaska site resulted from: (1) the data used for establishing the equation are from 
days with observed soil temperatures $\geq 0^{\circ} \mathrm{C}$ only; and (2) the assignment of predicted soil temperatures below freezing as $0^{\circ} \mathrm{C}$. Predicted soil temperatures for 6 of the 7 development sites (FL, OR, TN, AZ, MT, MI) show close correspondence with observed soil temperatures (Fig. 3).

Predicted soil temperatures from the regional equations and observed soil temperatures were strongly correlated in all 19 simulations (Table 4). While the number of days with estimated errors within $\pm 2.0^{\circ} \mathrm{C}$ ranged from 46 to 82 , averaging $60 \%$ (data not shown); the number of days with errors within $\pm 3.5^{\circ} \mathrm{C}$ ranged from 64 to 96 , averaging $84 \%$ of the year. Values of $\mathrm{R}^{2}$ ranged from 0.85 to 0.96 and the standard error of estimates ranged from 1.5 to $2.9^{\circ} \mathrm{C}$. The model responds to changes of both temporal and spatial dimensions with reasonable accuracy (Table 4).
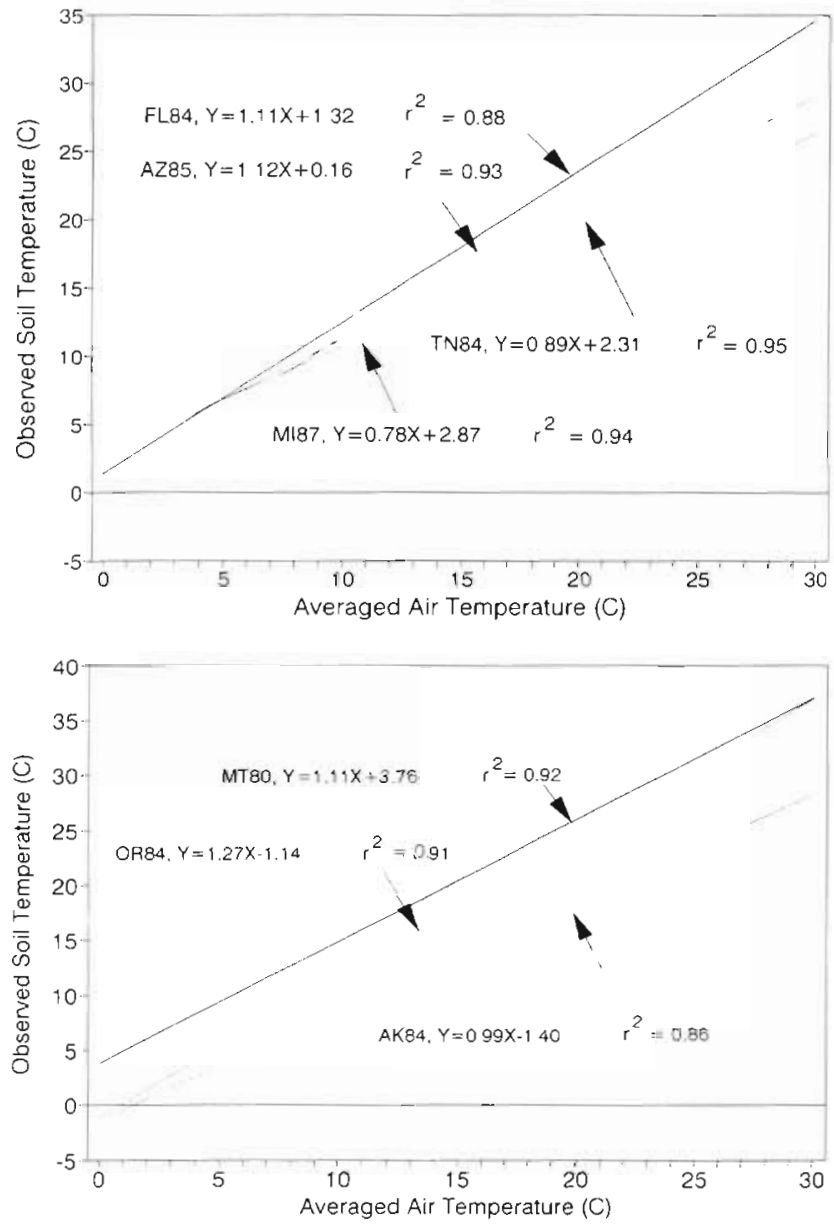

Fig. 2. Relationships between air temperatures $\left({ }^{\circ} \mathrm{C}\right)$ after 11 -day running averages and soil temperatures $\left({ }^{\circ} \mathrm{C}\right)$ at $10 \mathrm{~cm}$ depth for the 7 madel-development sites representing different climatic regions in the U.S. The equation for the site in Alaska was generated using only the days when observed mean soil temperatures are $\geq 0^{\circ} \mathrm{C}(\mathrm{N}=169)$; the others were from 365 -day data for the given years

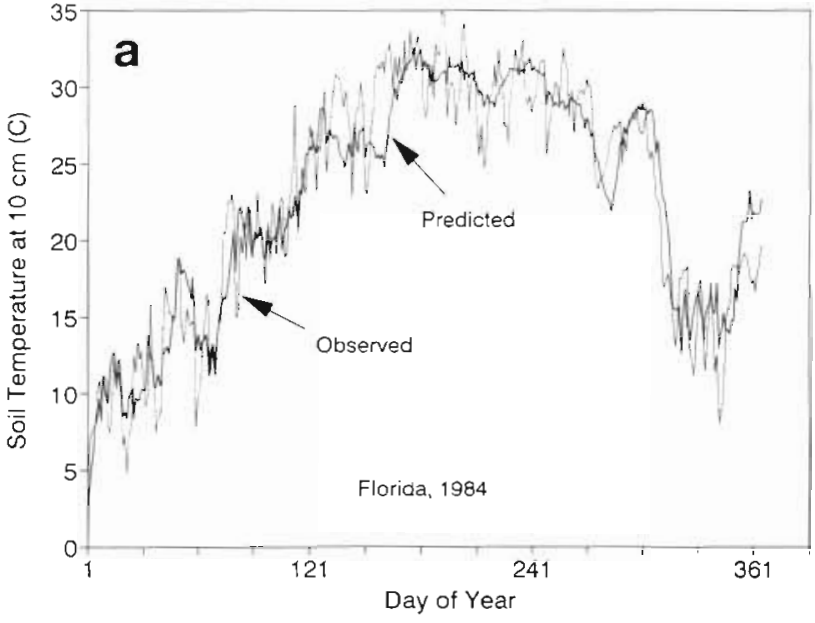

Fig. 3. Comparisons of predicted daily soil temperatures with observed values at $10 \mathrm{~cm}$ depth for the 7 model development sites: (a) FL84, (b) OR84, (c) AK84, (d) TN84, (e) AZ85, (f) MT80, and (g) MI87

Although significant errors existed between the predicted and observed soil temperatures for the Alaska site (Fig. 3c, Table 4), the result was better than that achieved by not assigning $0^{\circ} \mathrm{C}$ to the days when the predicted soil temperature was $<0^{\circ} \mathrm{C}$, because the regression equation was generated from the days with observed soil temperatures $\geq 0{ }^{\circ} \mathrm{C}$. Using all $365 \mathrm{~d}$ of data for the regression equation improved winter-time predictions of soil temperature, but underestimated actual soil temperatures during growing season. Also, a significant improvement in prediction of soil temperature could be achieved for the Alaska site if the constant rate scalers $\left(M_{1}\right.$ and $\left.M_{2}\right)$ were tuned for this site. For soil biological processes, it is more important to have a better soil temperature estimation during the growing season than to have better estimation during the winter time for sites like Alaska.

The predictions of soil temperature from some of the data sets used for model testing are better than the predictions from the data used for model development. Although regional equations should be tested for each new area, these results suggest that most sites within the same climatic region could use the same equation. However, both $F$ - and $t$-tests showed there were significant differences between each of the 7 regional equations and an aggregated equation as well as the differences among the 7 regional equations at the 0.05 level. Substantial differences exist between the results from the regional equations and the aggregated equation for the 7 model-development sites (Table 5). Thus, it may not be appropriate to use a single regression equation to predict daily soil temperature from daily air temperature over a continent. 

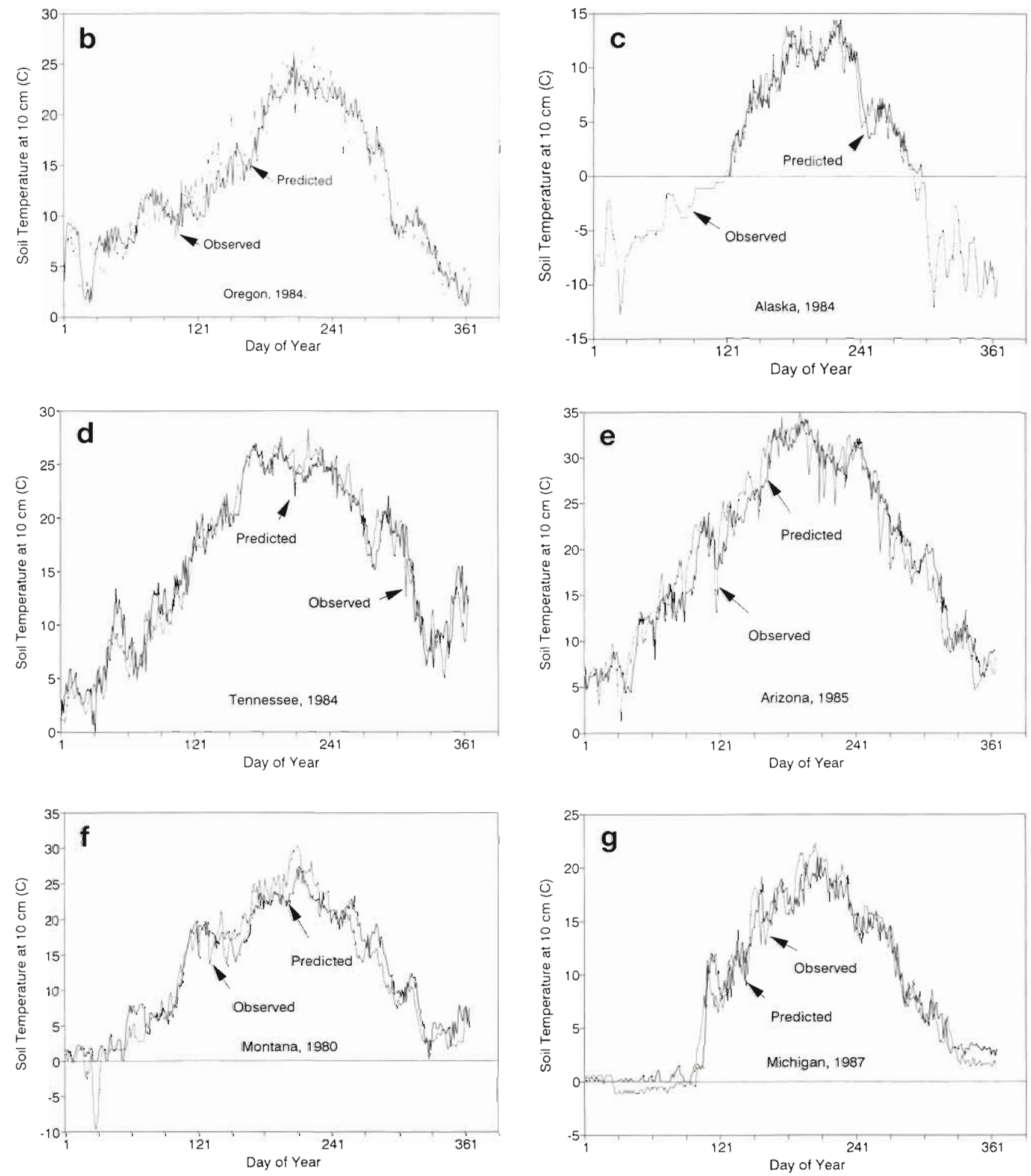

For all 7 model-development sites, the average annual soil temperature at a $10 \mathrm{~cm}$ depth is higher than the average annual air temperature (Table 1). Higher average soil temperatures have been reported before (Shulgin 1978, Toy et al 1978) and might be expected

in light of the low specific heat of soil and the reduced air mixing that usually occurs in the air layer adjacent to the soil surface (Toy et al. 1978). The variations range from 0.6 at $\mathrm{TN}$ to $4.6^{\circ} \mathrm{C}$ at $\mathrm{MT}$; these differences are probably caused by climate. For example, larger difference be- 
Table 4. Frequency analyses of predicted soil temperatures for all 19 simulations including 7 for model development sites and 12 data sets for model testing

\begin{tabular}{|c|c|c|c|c|}
\hline Abbrev. & $\begin{array}{r}\% \text { of days } \\
\quad \leq 3.5^{\circ} \mathrm{C}\end{array}$ & $\begin{array}{c}\text { ith error of: } \\
>5^{\circ} \mathrm{C}\end{array}$ & $\mathrm{R}^{2^{\mathrm{d}}}$ & $S E^{b}$ \\
\hline FL84" & 81 & 5 & 0.89 & 2.6 \\
\hline $\mathrm{FL}_{87^{+}}$ & 83 & 6 & 0.88 & 2.7 \\
\hline FL84p & 84 & 6 & 0.88 & 2.4 \\
\hline OR84. & 91 & 1 & 0.91 & 2.0 \\
\hline $\mathrm{OR}^{\circ} 8^{+}$ & 93 & 2 & 0.93 & 1.9 \\
\hline MI87 & 96 & 0 & 0.96 & 1.5 \\
\hline $\mathrm{Ml}^{189^{+}}$ & 78 & 9 & 0.93 & 2.2 \\
\hline NY87p & 90 & 2 & 0.95 & 1.8 \\
\hline TN84* & 95 & 1 & 0.95 & 1.8 \\
\hline $\mathrm{TN} 87^{+}$ & 95 & 1 & 0.95 & 1.7 \\
\hline NC83p & 77 & 4 & 0.95 & 2.1 \\
\hline$A Z 85^{\circ}$ & 87 & 2 & 0.94 & 2.3 \\
\hline$A Z 89^{\circ}$ & 82 & 7 & 0.94 & 2.3 \\
\hline NM85p & 91 & 0 & 0.95 & 2.2 \\
\hline AK84 " & 64 & 28 & 0.85 & 2.9 \\
\hline $\mathrm{AK} 89^{+}$ & 70 & 18 & 0.92 & 2.2 \\
\hline MT80 & 85 & 4 & 0.94 & 2.3 \\
\hline MT83 ${ }^{\dagger}$ & 82 & 3 & 0.94 & 2.2 \\
\hline MT80p & 80 & 7 & 0.95 & 1.9 \\
\hline \multicolumn{5}{|c|}{$\begin{array}{l}\text { "Coefficient of determination from linear regression be } \\
\text { tween observed and predicted soil temperatures } \\
{ }^{1} \text { Standard error for predicted soil temperature }\end{array}$} \\
\hline \multicolumn{5}{|c|}{$\begin{array}{l}\text { - Data sets used for model development } \\
\text { 'Data sets used for model testing on temporal dimension; } \\
\text { data sets denoted by p were used for model testing on } \\
\text { spatial dimension }\end{array}$} \\
\hline
\end{tabular}

tween air and soil temperatures at MT may result from both a longer time period of snow cover during winter and less precipitation during summer. Explanation for this can be developed from the use of detailed, physical models of soil temperature.

Relative annual soil respirations estimated from the predicted soil temperatures were slightly less than those determined using measured soil data (Table 6). As expected, the relative errors increase with an increase in the $Q_{10}$ value. For any given day, large errors in predicted soil temperature would cause substantial errors in the predicted soil respiration, but the errors in predicted soil. temperature were not strongly biased so the annual estimates of soil respiration had small but consistent relative errors.

Soil temperatures for deciduous and coniferous forests at the Tennessee site, 1984, were simulated using LAI of 5 (Fig. 4). The period of simulation for the deciduous forest was from Julian Day 97 to 307 (Hutchison \& Baldocchi 1989). After leaf emergence, the warming rate of soil temperature was substantially slowed down; after leaves senesced, the soil eventually reached the same temperature as that of bare ground. For coniferous forest, the influence of vegetation on soil temperature lasted the entire year. Soil tem-
Table 5. Comparison of soil temperature predictions from regional equations $(R)$ and aggregated equation ( $A$ ) for all 7 model development sites

\begin{tabular}{|c|c|c|c|c|}
\hline \multirow[t]{3}{*}{ Site abbrev. } & \multicolumn{4}{|c|}{$\%$ of days with error of: } \\
\hline & \multicolumn{2}{|c|}{$\leq 3.5^{\circ} \mathrm{C}$} & \multicolumn{2}{|c|}{$>5^{\circ} \mathrm{C}$} \\
\hline & $\mathrm{R}$ & A & $\mathrm{R}$ & A \\
\hline FL84 & 81 & 69 & 5 & 13 \\
\hline OR84 & 91 & 80 & 1 & 3 \\
\hline MI87 & 96 & 88 & 0 & 3 \\
\hline TN84 & 95 & 87 & 1 & 2 \\
\hline AZ85 & 87 & 78 & 2 & 3 \\
\hline AK84 & 64 & 35 & 28 & 38 \\
\hline MT80 & 85 & 68 & 4 & 20 \\
\hline
\end{tabular}

Table 6 . Percent errors of annual soil respiration calculated from the predicted daily soil temperatures and measured soil temperatures (Eq. 7) with various $Q_{10}$ values at the 7 model develonment sites

\begin{tabular}{lccc}
\hline Site abbrev. & $Q_{10}=2.0$ & $Q_{10}=2.4$ & $Q_{10}=3.0$ \\
\hline FL84 & -2 & -2 & -4 \\
OR84 & -1 & -2 & -3 \\
MI87 & -1 & -2 & -4 \\
TN84 & -1 & -1 & -2 \\
AZ85 & -1 & -2 & -3 \\
AK84 & -1 & -1 & -2 \\
MT80 & -1 & -3 & -6
\end{tabular}

"During the period that observed soil temperatures $\geq 0^{\circ} \mathrm{C}$

perature under forest cover in the northern hardwood ecosystem increases gradually compared with that at bare ground and reaches the maximum in August (Armson 1977) which agrees well with the trends in Fig. 4

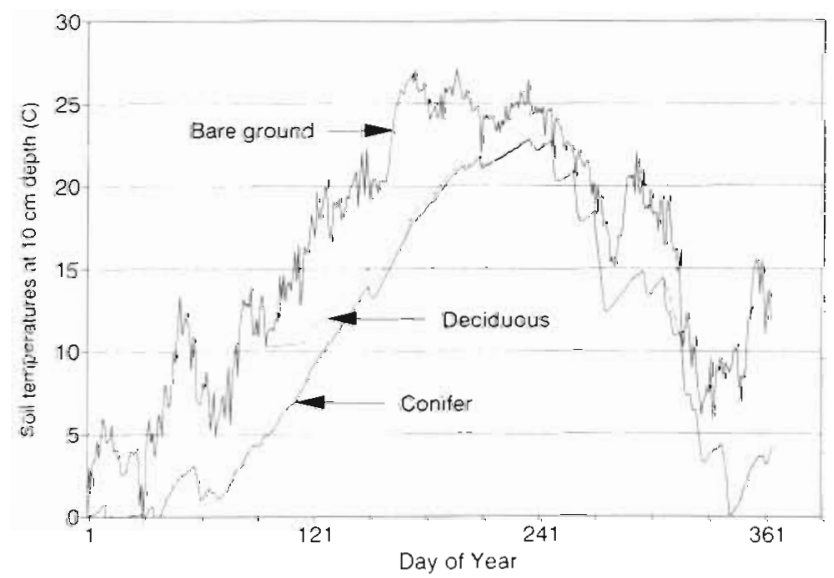

Fig. 4. Simulation of soil temperatures for confer and deciduous forests using the Tennessee, 1984, climate data. The simulation results are compared to the predicted soil temperatures for bare ground (Fig. 3d) 


\section{CONCLUSIONS}

Daily soil temperature at $10 \mathrm{~cm}$ depth for various sites and years may be predicted from daily air temperature, once equations have been established for different climatic regions. For site-specific applications, the accuracy of the predictions can be improved by determining if snowpack is present. The predicted soil temperatures are reasonably accurate for simulating biological processes, such as soil respiration, on an annual time step. We suggest that this methodology may be appropriate for predicting daily soil temperature from daily air temperature at large scales, because thousands of weather stations can be generalized into a few regions and the sites within a region may use the same equation. It may be possible to estimate soil temperature under vegetation cover at regional and continental scales using LAI estimated from satellites.

Acknowledgements. Funding for this research was provided by the National Aeronautics and Space Administration grant NAGW-952, National Science Foundation grants BSR8817965 and BSR-8919646. We thank 3 anonymous reviewers for their valuable comments on the manuscripts.

\section{LITERATURE CITED}

Armson, K. A. (1977). Forest soils: properties and processes. University of Toronto Press, Toronto

Asrar, G., Fuchs, M., Kanemasu, E. T., Hatfield, J. L. (1984) Estimating absorbed photosynthetic radiation and leaf area index from spectral reflectance in wheat. Agron J. $76: 300-306$

Buringh, P. (1984). Organic carbon in soils of the world. In Woodwell, G. M. (ed.) The role of terrestrial vegetation in the global carbon cycle: measurement by remote sensing SCOPE 23, John Wiley \& Sons, Chichester, p. 91-109

Campbell, G. S. (1977). An introduction to environmental biophysics. Springer-Verlag, New York

Cermák, V., Bodri, L., Šafanda, J. (1992). Underground temperature fields and changing climate: evident from Cuba. Palaeogeogr. Palaeoclim. Palaeoecol. (Global Planet. Change Sec.) 97: 325-337

Edwards, N. T (1975). Effects of temperature and moisture on carbon dioxide evolution in a mixed deciduous forest floor Soil Sci. Soc. Am. Proc. 39: 361-365

Hasfurther, V. R., Burman, R. D. (1974). Soil temperature modeling using air temperature as a driving mechanism. Trans. Am. Soc. Agric. Eng. 16: 78-81

Hutchison, B. A., Baldocchi, D. D. (1989). Forest meteorology. In: Johnson, D. L., Van Hook, Robert, I. (eds.) Analysis of biogeochemical cycling processes in Walker Branch Watershed. Springer-Verlag, New York, p. 21-95

Jarvis, P. G., Leverenz, J. W. (1984). Productivity of temperate, deciduous and evergreen forests. In: Lange, O., Nobel, P., Osmond, C., Ziegler, H. (eds.) Physiological plant ecology 12D. Springer-Verlag, New York, p. 233-280
Jemison, G. M. (1934). The significance of the effect of stand density upon the weather beneath the canopy. J. For 32: $446-451$

Karl, T. R., Baldwin, R. G., Burgin, M. G. (1988). Time series of regional seasonal averages of maxımum, minimum, and average temperature, and diurnal temperature range across the United States: 1901-1984. Historical Climatology Series 4-5. National Climatic Data Center, National Oceanic and Atmospheric Administration, Asheville, NC

Lee, R. (1978). Forest microclımatology. Columbıa University Press, New York

Li, T.-T (1926). Soil temperature as influenced by forest cover Yale Unuversity, School of Forestry, Bull. No. 18, New Haven

Munn, L. C., Buchanan, B. A., Nielsen, G. A. (1978). Soil temperatures in adjacent high elevation forests and meadows of Montana. Soil Sci. Soc. Am. J. 42: 982-983

Nemani, R. R., Running, S. W. (1989). Testing a theoretical climate-soil-leaf area hydrologic equilibrium of forests using satellite data and ecosystem simulation. Agric. For Meteorol 44: 245-260

Neter, J., Wasserman, W., Kutner, M. H. (1990). Applied linear slatistical methods. Irwin, Inc., Boston

Nobel, P. S., Geller, G. N. (1987). Temperature modelling of wet and dry desert soils. J. Ecol. 75: 247-258

Parton, W. J. (1984). Predicting soil temperatures in a shortgrass steppe. Soil Sci. 138: 93-101

Peterson, D. L., Spanner, M. A., Running, S. W., Teuber, K. B. (1987). Relationship of thematic mapper simulator data to leaf area index of temperate coniferous forests. Remote Sensing Environ. 22: 323-341

Pritchett, W L., Fisher, R. F. (1987). Properties and management of forest soil. John Wiley \& Sons, New York

Qashu, H. K., Zinke, P. J. (1964). The influence of vegetation on soil thermal regime at the San Dimas Lysimeters. Soil Scr. Soc. Am. Proc. 28: 703-706

Raich, J. W., Schlesinger, W. H. (1992). The global carbon dioxide flux in soil respiration and its relationship to vegetation and climate. Tellus 44B: 81-99

Running, S. W., Peterson, D. L., Spanner, M. A., Teuber, K. B. (1986). Remote sensing of coniferous forest leaf area. Ecology 67: 273-276

Shulgın, A. M. (1978). Soil climate and its control. U.S. Department of Commerce, National Technical Information Service, Springfield, VA

Soil Conservation Service (1975). Soil taxonomy: a basic system of soil classification for making and interpreting soll surveys. Agriculture Handbook No. 436

Stathers, R. J., Black, T A., Novak, M. D. (1985). Modelling soil temperature in forest clearcuts using climate station data. Agric. For. Meteorol. 36: 153-164

Strahler, A. N., Strahler, A. H. (1989). Elements of physical geography. John Wiley \& Sons, New York

Thunholm, B. (1990). A comparison of measured and simulated soil temperature using air temperature and soil surface energy balance as boundary condition. Agric. For. Meteorol. 53:59-72

Toy, T. J., Kuhaida, A. J., Munson, B. E. (1978). The prediction of mean monthly soil temperature from mean monthly air temperature. Soil Sci. 126: 181-189

Tucker, C. J. (1979). Red and photographic infrared linear combinations for monitoring vegetation. Remote Sensing Environ. 8: 127-150

Manuscript first received: November 18, 1992

Revised version accepted: March 29, 1993 